\title{
Demak Kingdom: Study of Environmental Condition and Geographical
}

\author{
Hendro, Eko Punto ${ }^{1}$, Sari, Suzanna Ratih ${ }^{2}$, Saputro, Siddhi $^{3}$, Indriyanto ${ }^{4}$ \\ ${ }^{1}$ Cultural Department, Faculty of Cultural, Diponegoro University, Semarang Indonesia \\ ${ }^{2}$ Archietectural Department, Faculty of Enginering, Diponegoro University, Semarang \\ ${ }^{3}$ Marine Department, Faculty of Fish and Marine, Diponegoro University, Semarang \\ ${ }^{4}$ Historical Department, Faculty of Cultural, Diponegoro University, Semarang Indonesia
}

\begin{abstract}
Many experts have written about the history of the Demak kingdom, therefore the role of this kingdom in politics, economics and especially in the spread of Islam in Indonesia in the past. With the geophysiographical, historical and archaeological approach used in this study, it can be revealed about the environmental conditions and the location of the palace and the royal city of Demak. The research methods used in this research are observation, geophysiographical (drilling, geoelectrical measurement), historical (reading of documents) and archaeological (test pit excavations) methods, to obtain credible conclusions. The result is that the kingdom, which has a fairly large influence in the archipelago, is located on the island of Demak between Java and the Muria peninsula, which is still in a separate condition, which is surrounded by swamps, rivers and the sea. the tombs of kings, the names of places/villages (toponyms), have proven that the existence of the central city of the kingdom is concentrically arranged and the settlement patterns are grouped according to position, profession, ethnicity and religion.
\end{abstract}

\section{Introduction}

Historical sources have shown that the Demak kingdom was the first Islamic kingdom in Java, which was instrumental in Islamization in Indonesia. Together with Wali Songo in the 15-16th century AD, the Demak kingdom succeeded in exerting Islamic influence in areas including Java, Kalimantan, Sulawesi, Maluku and so on, and together with the Aceh Kingdom, it was able to instil Islamic influence in most areas. Archipelago archipelago. Such is the role of the Demak kingdom in paving the way for the entry and development of Islam in Indonesia, so this is an excellent service for the nation and state of Indonesia, where most of the population embraces Islam. The beginning of the history of the formation of the cultural assets of the Demak area began around the 15th - 16th century with the selection of the area as an Islamic centre ("Islamic Center") by the Wali Songo, which later developed into the first Islamic kingdom on the island of Java. Although politically, the influence of the Demak kingdom was not as significant as the previous kingdoms, such as the Srivijaya or Majapahit kingdoms, this kingdom was very instrumental for the 
Indonesian people because this kingdom had succeeded in bringing and developing Islam in Indonesia, especially in Java.

The research is also focused on studying the current geophysiographic environmental conditions of the Demak region to be predicted in the past. Choosing the location or establishment of a capital city (state) of the kingdom will undoubtedly consider ecological aspects, both physical and non-physical. Following the role of a royal capital, environmental aspects must support economic, political, defence and cultural interests. History has also proven that the emergence of a city, especially in Java, especially the capital of a kingdom in the past, was greatly supported by suitable environmental conditions, for example, in areas with fertile land, on the coasts, on the banks of river estuaries, protected by mountains, islands. Island or sea and so on. For example, example, the Srivijaya kingdom was located on the coast and river of the trade route, the Majapahit kingdom was located near the Brantas River and protected by Mount Arjuna and Mount Wilis, the Banten kingdom was on the offshore coast, the Surakarta kingdom was in a fertile area on the banks of the Solo River. It is protected by Mount Merapi, Mount Merbabu, Mount Lawu and the Indonesian Ocean. Considering the historical development of Demak, both its social development and the development of its government, of course, has an impact on changes in the landscape with its land use, due to natural processes and human activities after the kingdom era, as seen today. In addition, there are very few physical and non-physical / historical relics of the former palace or parts of the royal city, although the traces are still vague. This is thought to be one of the difficulties in determining the geophysiographic conditions of the kingdom. The geophysiographical conditions that have changed are the structure and morphology of the soil rock layers in the Demak area, changes in coastline, changes in river flow patterns that pass through the Demak area and soil fertility conditions so that it is suitable for human life. Therefore, the initial research aims to investigate and determine the distribution of rock layers and the sedimentation process that occurs in the area around the city of Demak, so it will be possible to know the geophysiographic conditions during the Demak kingdom and its changes to the present.

\section{Research Method}

Such is the significance and role of the Demak kingdom for the Indonesian people, so it is necessary to thoroughly research the site of the former centre of the Demak Kingdom. Geographical and geological environmental data can help a lot in choosing the location of the centre of the kingdom, which is obtained through observation and drilling, geoelectric measurements and test pit excavations carried out around the town square of Demak to the coastal area in the Moro Demak area. Maps are also used as data, including topographic maps, cadastral maps, and satellite maps of Semarang, Demak, to Jepara. In addition, data from ethnohistorical and ethnoarchaeological sources can still be used to see the urban structure patterns, such as place names (toponyms) and the traditions or behaviour of the Demak people that still reflect the past. Even in this situation, you still have to pay attention to the changes that occur due to the time gap. Historical sources search for old manuscripts, and foreign news sources can still be carried out to reveal the condition of this central site of the Demak kingdom. In addition, of course, comparative studies can also be carried out to strengthen the analysis of the reasons for choosing the location, city condition and the palace of the Demak Kingdom. 


\section{Result and Discussion}

\subsection{Land Use}

Most of the rivers in the Demak area flow towards the Northwest (Java Sea), there is only one river that flows to the East, namely the Yuwono River ("Bengawan Silugonggo"), which during the kingdom era was a reasonably large river and was connected to the river. Attack / Warp. Based on the results of hand drilling at two points, which are on the banks of the Tuntang Lama River, namely in front of the Regency and in Mlaten / Saudagaran, it turns out that there are sand and clay sediments found at a depth of $4.5 \mathrm{~m}-10 \mathrm{~m}$, this proves that at about this depth is the bottom of the old Tuntang River. Thus, if it is related to the depth of the settlement floor, the river's depth during the kingdom period was estimated to be between $2.00 \mathrm{~m}-7.5 \mathrm{~m}$, and the Tuntang River would be able to be navigable for merchant ships. The condition of groundwater formation is generally caused by silty sand sediments around the bend of the Tuntang River, which is shown on the geohydrological map and the results of drilling, geoelectric and test pit measurements in the 2000 study, which may have infiltration from the Tuntang River stored in natural embankments ("levee"). , besides that, the Tuntang River itself is also a source of freshwater. When viewed as the Demak area, the Demak area, especially urban areas, has the best groundwater content for daily living needs compared to other areas. From the description above, it is possible that the Demak kingdom was also supported by strategic environmental conditions for economic and political interests.

Moreover, the Demak kingdom also has a mission to develop Islam so that environmental conditions can support this interest. In terms of its layout, the Demak kingdom is located in Central Java, allowing it to reach West Java, East Java, and even western and eastern parts of Indonesia. The condition of Java Island from the past to the present is very dense with human activities in political, economic and cultural aspects. It is denser than other islands in Indonesia. Most of the major kingdoms that had existed in Indonesia were centred on the island of Java. It is possible that Java's environmental conditions are quite good and strategic to support increasingly complex human activities, including the large number of volcanoes that have resulted in a large number of fertile volcanic soils, many rivers that can support agricultural, transportation and trade activities. Moreover, its location in the entire archipelago makes it easy to communicate with Indonesia's western and eastern regions. For more details, it can be checked in the image below.

From the picture, it appears that the Demak district was located on an island that arose from sedimentation processes in ancient times. Demak is also button sediment that connects the mainland of Java and the Muria mainland. Demak District is indeed surrounded by tidal marshes. However, it seems that Demak does have advantages over the other islands (button sediments) around it, namely the land is higher, there is a river (the Tuntang lama river) that crosses it and has groundwater (for wells) which is quite good. This is why the Demak district was chosen as the centre of the royal government rather than the surrounding area. However, during the period of the Demak kingdom, the islands around Demak also had many settlements, this can be seen from the results of research and archaeological excavations conducted by the Yogyakarta Archeology Center in the Moro and Tridonoharjo areas, which found fragments of Chinese and local ceramics and building foundations [2]. 


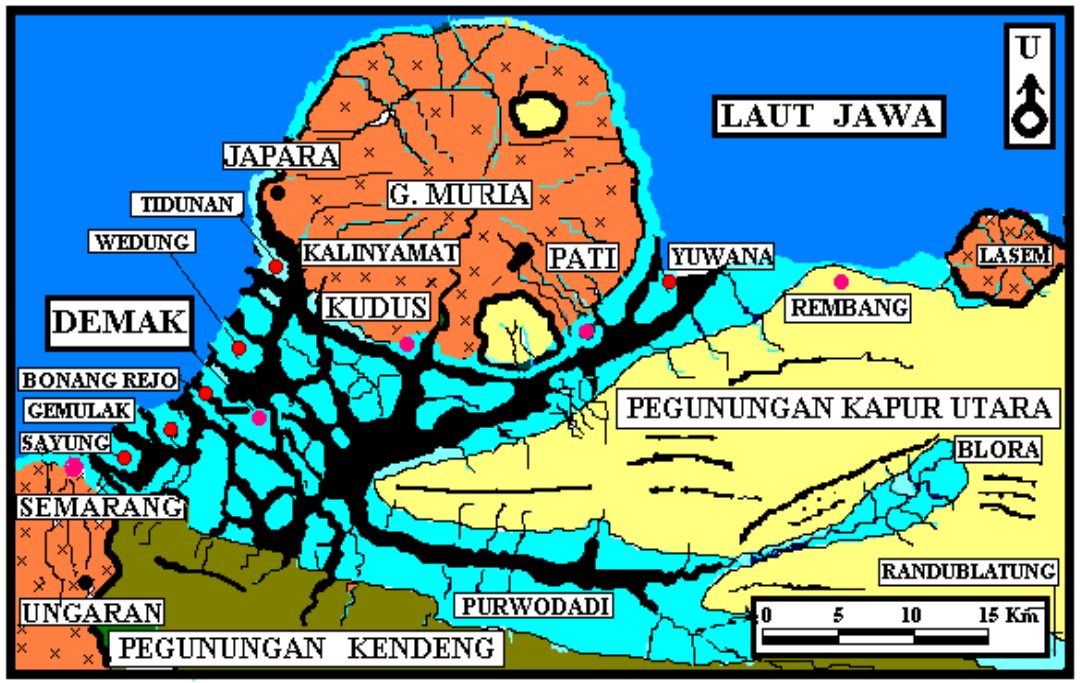

Geophysiographical condition of Demak-Grobogan Area around 15-16 AD

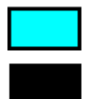

Tidal swamp / river

Beachfront area

River / swamp shipping lanes

Fig.1.

Historical and Archaeological Data Analysis the oldest historical sources about Demak's condition are ancient Javanese texts recorded in 1358 AD. The elaborated this text. Pigeaud [14], which was contemporary and related to the Nagarakertagama book, is a book that describes the ins and outs of the Majapahit kingdom in its heyday. This text was found to be incomplete, anonymous and many parts missing. However, this text describes the king's orders to sail (anambangi) rivers and beaches throughout Java to oversee the areas on the banks of the river or coast, so experts have named this text "Ferry Charter". In this case, Demak and several other areas that are on the banks of rivers or beaches, including Surabaya, Godong, Pamotan, Jipang, Ngawi, Waringin Pitu, Ketapang, Canggu and others, are always visited or supervised by officers of the Majapahit kingdom by sailing. by river or shore. Here is a little excerpt from "Ferry Charter", 1358:

.... nusa, i temon, parajengan, i pakatekan, $i$ wunglu, ...........i mireng, ing dmak, $i$ klung, ....... $i$ godong, .......i canggu, ......i waringin pitu, ......i pamotan, ........i curabhaya, muwah prakaraning naditira pradeca sthananing anambangi i madanten, .......... i jipang, $i$ ngawi, $i$ wangkalang, .....sarwwe ika ta kabeh, naditirapradeca, sthananya ng anambangi sayawadwipamandala, ngunika-lanyanghyang, ajna haji pracasti, rajasanagaralancana, kuneng tingkah ikang anambangi sayawadwipamandala, makadi panji marggabhaya, kyajaran rata, mwang panjyangraksaji, kyajaran ragi, kewala swatantra,

(Pigeaud, 1960: I. 110-112).

From the incomplete text above, it can be interpreted that Demak (dmak) is located on an island, on the shore or the riverbank, as an area (place) that can (must) be reached by boat by river or sea. From the text, at least it can be seen that the Demak area in the Majapahit era was covered by water from rivers, swamps or the sea. According to historical 
sources, during the Dutch colonial rule, the Demak area was a swampy area prone to flooding. So since that time, the Dutch government has continuously managed this area with quite a large amount of funds, including making canals and dams to manage river water and swamps so that they are not dangerous and so that they are more practical for example for agriculture. There are four artificial rivers (canals) built by the colonial government. Two canals stretch north and south, namely the Buyaran Canal, which is in the west of the city of Demak and the Jajar Canal, which is in the eastern part of the city. Flood in the city of Demak. In addition, two transverse canals were built, which connected the rivers to the west and east of the city of Demak, respectively. It is also told in the Dutch source that with the construction of these canals, some swamps could be drained, and the danger of flooding and famine could be overcome, although not wholly [8].

In his work, H.J. de Graaf [3], an Indonesian historian, states that the location of the Demak kingdom was very profitable for both trade and agriculture. In ancient times Demak district was located on the strait coast separating the Muria Mountains from Java. This strait was relatively wide and navigable well, so merchant ships from Semarang could take a shortcut to sail to Rembang, but since the 17 th century, it seems that this strait has become difficult to navigate again. He also said that in the 16th century, Demak had become a hoarding place for the trade-in rice originating from agricultural areas next to the strait, with its calm waters for shipping. From historical news, it is also known that in addition to a port near the city centre, in ancient times, the Demak kingdom also had another port, namely in Jepara. At that time Jepara was under the supervision of Pati Unus (Pangeran Sabrang Lor), the son of Raden Patah (the first Sultan of Demak). At the turn of the year 1512-1513, the kingdom of Demak launched a sea attack on the port in Malacca, which was prepared from the port of Jepara. Malacca, which was the centre of trade in Southeast Asia, was under Portuguese control. From this, it can be estimated that Jepara is a military port prepared by the authorities in Demak to replace the port of Demak itself, which is increasingly silting [17].

With the strait separating the Muria Mountains from Java, it is estimated that the central city of the Demak kingdom is indeed not far from the coast. This will be one of the research targets, like the actual geomorphological condition of the Demak area in the past, during the heyday of the Demak kingdom. In addition, other targets to be achieved are to determine the environmental conditions of the Demak area in the past so that it is suitable for the growth and development of the royal city of Demak. Avoiding the danger of flooding, soil fertility factors and its strategic location for political, economic and religious activities, perhaps all these factors certainly support the choice of the location of the centre of the Demak kingdom.

Regarding the location of the centre of the kingdom, it is estimated to be in the centre of the present city of Demak. This can be seen in the presence of the Grand Mosque and a square in front of it, the tombs of Demak kings in the mosque complex, the names of villages or streets (toponyms) around the Grand Mosque the square. Which still reflects the settlements in the past. The Grand Mosque and the square are thought to have been the mosque and plaza of the Demak kingdom in the past that are remaining today, and of course, the location of the Demak palace is also not far from that place. Through comparative studies, the Demak palace is undoubted to the south of the mosque and the square. Now the Grand Mosque and Demak square have been restored and renovated.

\subsection{Historical data findings}


Tome Pires was a Portuguese who had come to Indonesia around 1513 as a business representative and supervisor of the cargo of a Portuguese ship. He visited the cities on the North coast of Java. At least he knew the cities from Cirebon to Gresik (Armando Cortesao, 1944: xxv xxvi). According to Tome Pires, Demak is one of the areas on the North coast of Java, which is located between Semarang and Tidunan (Tedunan). This area is wider than Cirebon, Tegal, Semarang and Jepara. The population is far more than that of the area. At that time, Cirebon had a population of 1000 people, Tegal 4,000 people, Semarang 3,000 people, Jepara 2000 people, and Demak had a population of about 8,000 to 10000 families. The ruler of this area was named Pate Rodim, a son of the king of Majapahit, Batara Brawi $\neg$ jaya. He was appointed ruler of Java by his supporters. His territory not only covers Java but also reaches Palembang, Jambi, Monomby (?) And several other islands. This area exports rice and other foodstuffs to Malacca. After the Portuguese succeeded in occupying Malacca in 1511, Demak and his vassal area, Jepara, invaded Malacca under Pati Unus, a ruler in Jepara, around 1512. Tome Pires analysed the importance of Demak's invasion of Malacca because the area is an important trade key for the Demak kingdom. Besides exporting agricultural products to Malacca, Demak also fulfils the needs of traders from Malacca who come to that place. These traders came from Gujarat, Keling, China and Bengal. This, for Demak, was of great benefit [6].

Regarding the condition of the city and the palace of Demak, Tome Pires identifies it is located on the bank of a river and not far from the beach. The river is indeed important for shipping and trading activities, but ships from outside cannot enter to sail it unless the tide is high. From Tome Pires' news, it can be seen that Demak has an important economic and political role in Java. Although he did not describe the kingdom's location or the residence of the ruler in Demak at that time, he was sufficient to explain that the city was the centre of political power in Java. So, it can be assumed that in Demak, there was once a place where the rulers resided and carried out the government. Another Portuguese writer, Fernando Mendez Pinto, was a famous explorer in Portuguese history (Cortesao, 1944: xviii). He witnessed the Demak invasion of Panarukan and the death of Sultan Trenggono (De Graaf, 1974: 88). In this attack, Sultan Trenggono suddenly died. After that, there was a battle between the rulers in Cirebon and the king of Panarukan. With around 6,000 to 7,000 soldiers, Cirebon attacked Panarukan and killed 40 Panarukan. Cirebon's actions came under counterattack from Panarukan. They can kill around 10,000 Cirebon people. The Panarukan soldiers also attacked Demak, destroying about 12 places and burning houses to ashes. They also took large amounts of gold and silver (Valen $\neg$ tijn, 1862: 330). The number of Cirebon and Panarukan soldiers recorded by Fernando Mendez Pinto needs to be questioned because Tome Pires also reported that Cirebon had only about 1000 people in the second decade of the 16th century. Perhaps this event caused the demise of the Demak palace. The Dutch writer, Francois Valentijn, who came to Java in the 17th century, did not write about the residence of the Demak ruler, but for the city of Jepara, he wrote it in detail [18]

Another source regarding the existence of the Demak palace came from a Dutchman named Fokker who had witnessed the ruins of the Demak palace in the early 19th centurytold in the book The Suma Oriental. He then rewrote it in his book entitled "Episoden uit de Tijd der Portugesche Heerschaapij in Oost Indie" [9]. After describing the condition of the Demak Mosque, which was quite old at that time, he then explained:

"Een strook ground, die tegenover den Messigit en aan de andere zijde der Aloen-aloen ligt, en achter door de rieveren begrensd, nog altijd Sitinggil door plaatselijke bevolking genoem, als de plaats waar de Sultans van Demak hun kraton hadden.De overal verspreid liggende gebrakken stenen en steenbroken en wat ik verder vond, lieten geen twijfel ober, dat ik daar rond ging over ruimte waar vroeger de uitgebreide verblijfplaats was van een vorts of vorstelijk persoon, met muren omringd en van poorten voorzein" (Fokker, 1809: 20). 
Translated:

A piece of land located opposite the mosque and on the side of the square, bordered by rivers, which the local people still call Sitinggil, is where the Sultans of Demak have their palaces. The scattered bricks and brick fragments, and what I found further, no doubt, that I had been around in a room (place) of a king or court person, which was equipped with walls (walls) and the doors (gates). "

Besides tracing the news of Tome Pires, Fokker also used another Portuguese source from Mendez Pinto, who had reported about the burning of the Demak palace by troops from Pasuruhan / Panarukan at the end of the Demak kingdom's reign. He also questioned whether the demak palace buildings collapsed because they were burned and destroyed by the troops from Panarukan? Although Fokker can still see the ruins of the Demak palace in the early 19th century, other Dutch people came to Demak in the mid-19th century, namely F.S.A. Clerg [5] and J.F.G. Brumund [4], no longer found the ruins of the Demak palace. At the beginning of the explanation, the two Dutch people always talked about the condition of the Demak mosque at that time, although it was old still well maintained. They no longer saw the ruins of the Demak palace by saying that in Sitinggil, which is located next to the square, it did not show any significant remains of the building because it was a Dutch building, namely Gudang Garam. However, Clerg still explains that the remains of bricks and small posts (umpak?) They can still be seen because residents keep their sacred items, and the local people refer to them as 'sitinggil stones'. Apart from the sources of the two Dutch people mentioned above, another source was found regarding constructing the Semarang - Joewana railway through Demak by the colonial government at the end of the 19th century. It is explained in this source that the construction of the railway was right through the centre of the Demak Palace [8]

There is a possibility that the complete disappearance of the ruins of the former palace wall of Demak was caused by the construction of the railway and by a 'Postweg' highway built by the colonial government during the Deandels administration 1810. A source from the Perfectur Semarang Report (February 1810) in the form of an archive of "Tusses Bestuur in Nederlandsch Indie: No. 2753", [7] states that:

for the plan to continue the construction of the "Postweg" road that crosses Demak faces considerable difficulties because besides crossing swamps and rivers, it also crosses the area in front of the Demak Mosque and the square, which according to the statement of the Regent of Demak, Raden Tumenggung Adinegoro, is the former palace of Demak (Patah) which was sacred to the people.

Furthermore, in a free translation, the source stated that if the Postweg road was continued, the Regent of Demak suggested negotiating and asking for permission from Pangeran Kadilangu. Apart from that, the Regent also appealed to the Honorable Lieutenant Governor-General Daendels to be strongly asked to consider this matter so that there would be no bigger chaos, such as what happened in Losari and Tegal. He also suggested that the Postweg road be turned in a semicircle to the south and end in the east of Demak. That is the only data found regarding the construction of the Daendels road, and no other data has been found. Because it is no longer known the end of the talks, dispute resolution or other matters that occurred in the Demak area related to the construction of the Postweg road. However, what can still be seen now is that the Postweg road has been completed and still cuts across the square and the former location of the Demak palace. There is an assumption that the main cause of the complete disappearance of the ruins of the Demak Palace was 
due to the road being hit by the Daendels road, which was followed by the construction of a railway and other buildings. Regarding the railroad that had been built by the colonial government since 1879 based on the Decree of the Governor-General of the Dutch East Indies dated December 1, 1879. [1] Referring to that decision, this railroad was built to the south of the main road (Daendels road), in the city of Demak right through the square aloon and parallel to Daendels Street. This means that this railroad also cuts the location of the former Demak palace. [2]

From the historical and archaeological facts that have been collected, it is known that there is a common pattern between cities and palaces that have existed in Java since the era of the Kadiri kingdom (Hinduism) to the relatively young Kraton, namely the Yogyakarta Palace. These palaces generally face north and have a square and sacred buildings (shrines/temples/mosques) in front of them, and there is a market not far from the palace. As the centre of the royal government, the palace is usually equipped with a bureaucratic audience (Pasewa Agung) which is given different names but has the same function, namely Sabha, Pasebhan, Pasewan and Setinggil. It turns out that such a phenomenon can also be found in the city of Demak, around the square's location, here there is the square, the Grand Mosque, there is Setinggil toponym, and there is also a market. With a comparative study and the concept of changing cultural traditions, of course, the location of the Demak Bintara palace can be guessed. However, to strengthen this assumption, other studies are needed $[1,14,16]$.

The location of the palace, mosque and square in an ancient city contains many symbolic meanings. The palace here symbolizes the ruler or power over the people, the mosque symbolizes religion as the protector of the people, while the square symbolizes the people themselves. The unity of the palace, mosque and square symbolizes the union between the rulers, religion and the people, or a Javanese concept of "jumbuhing kawulagusti".[3]. This concept is a reciprocal doctrine, namely the king's moral responsibility towards his people and the people's obligation to obey the king's orders, which means that the king must carry out the task of "njaga tata tentreming praja" (maintaining state security and tranquillity) and the people must always "ngemban dhawuh dalem" (carry out the king's orders). It seems that in ancient times the king also knew very well that the people always took refuge in religion to face the pressures of their environment. Therefore the king often acted as a representative of God or God who had absolute power and controlled religion and had a moral responsibility for the welfare of his people. Then this is manifested in the world of architecture, a unified palace, mosque and square.

\section{Conclusion}

From the descriptions of various things in previous chapters regarding the efforts to find and determine the location and development models of the Demak Bintoro royal centre site, it can be argued several things as a conclusion:

1. Demak in the Pleistocene era was still a deep basin flanked by three mountains, Mount Muria, North Cretaceous Mountains / Rembang and Kendeng Mountains. The coastline of the Demak area is along the button sedimentary deposits starting from the village of Tidunan to the West, passing W Gedung-Bonangrejo-Gemoelak-Sayung and Semarang.

2. The environmental conditions of the Demak area were quite favourable and strategic for the centre of the kingdom, from a political, economic, social and cultural perspective, which was also supported by underground water conditions that were good enough for the construction of wells. In addition to the relatively good environmental conditions, Demak was chosen as the centre of the kingdom, which was also strengthened by cultural legitimacy through a cosmological concept, namely the migration of the Majapahit 'wahyu kraton' to Bintoro Demak. 
3. From the travel records of the Portuguese named Tome Pires, it is known that the city of Demak is located between Semarang and Tidunan and is traversed by a river that can be navigated from the sea, although it has to wait for high tide. The Demak Palace is certainly in the city centre, but its location is unknown because very little physical data has been found. The only data is the Grand Mosque and the square which marks the centre of the royal city; of course, there was once a palace nearby. The foreign news sources that mention the city and the palace of Demak are only colonial sources from the 19th century. Generally, these colonial news writers have not seen the palace anymore, and only the names of the setinggil and the square are mentioned. However, a Dutchman named Fokker in the early 19th century had seen the ruins of the Demak palace near the mosque and the square before the construction of Daendels Street. It is probably the Daendels road that initially caused the loss of track of the Demak palace followed by the opening of the railroad because the location of the palace is thought to be south of the square, and the two roads passed.

4. Stratigraphic data from the test pit results suggest that ponds and rivers cover the Demak Palace. From this stratigraphic data, it is also known that the area as high as the ground and the area behind it is quite high in the position of the soil layer, so the two locations are thought to be the location of the same height (paseban) and the core of the Demak Palace. To the east of the palace location, there is a layer of soil, formerly a large pond; it is thought that it is the former location of the Tamansari complex. From this place, there is also the toponym 'bale kambang', which is a cosmological symbol of the king and his kingdom and the name of the king.

5. In the vicinity of the Grand Mosque, the square and the location of the former palace, the village names (toponyms) are found as ethnohistorical data. The names of the places (villages) indicate the pattern of urban community settlements in ancient times, grouped based on position, profession, ethnicity and religion, which surrounded the centre, namely the palace.

\section{References}

1. Adrisijanti, I. (1997). Kota Gede, Plered dan Kartasura Sebagai Pusat Pemerintahan Kerajaan Mataram Islam (+ 1578 TU - 1746 TU) : Suatu Kajian Arkeologi. Yogyakarta: Disertasi UGM.

2. Ambary, H. M. (1980). Catatan Singkat Kepurbakalaan Banten Lama. Analisis Kebudayaan Th. ! No. $1,117-127$.

3. Anom, I Gusti Ngurah. et.al. (1986). Laporan Pemugaran Masjid Agung Demak. JakartaYogyakarta: Proyek Pemugaran Masjid Agung Demak Bantuan Presiden.

4. Brumund, J. (1960). Bijdragen tot de Kennis van Het Hindoeisme op Java. VBG XXXIII .

5. Clerg, F. (1848). Een Episode Uit de Geschiesdenis van Majapahit en de Sultan Demak ads de Eerste Vorst op Java. The Hague: Zalt Homel.

6. Cortesao, A. (1944). The Suma Oriental of Tome Pires: An Account of the East, Seri Kedua, Jilid XXXIX dan XL. London: Hakluyt Society.

7. Daendels. (1810). Tusses Bestuur in Nederlandsch Indie: No. 2753. Semarang: Prefectur Semarang Report.

8. Encyclopedie van Nederlandsch Indie. (1917). The Hague, Leiden: M.Nijhoff, E.J. Brill. 
9. Fokker. (1809). Episoden Uit de Tijd der Portugesche Heerschapij in Oost Indie. 'sGravenhage: Martinus Nijhoff.

10. Gerdern, R. V. (2011, March 23). Conceptions of State and Kingship in Southeast Asia. The Journal of Asian Studies , 15-30.

11. Graaf, H.J. De and Pigeaud, Th.G. (1985). Kerajaan-kerajaan Islam di Jawa. Jakarta: Grafitti Press..

12. Leeder, M. (1982). Sedimentology Process and Product. London: G. Allen and Unwin.

13. Moedjanto, G. (1990). The Concept of Power in Javanese Cukture. Yogyakarta: Dajahmada University Press.

14. Pigeaud, T. (1960). Java in the Fourtenth Century I-IV. The Hague: Martinus Nijhof.

15. Reading, H. (1981). Sedimentary Environmets and facies. London: Blackwell Scientific Publication.

16. Sedyawati, E. (1983). Keadaan Masyarakat Jawa Kuna Masa Kadiri dan Masalah penafsirannya. Proccedins Pertemuan Ilmiah Arkeologi. Jakarta: Puslit Arkenas.

17. Tjandrasasmita, U. (1985). Kota Pemukiman Masa Pertumbuhan Kerajaan-kerajaan Pengaruh Islam di Indonesia (Penerapan Arkeologi dan Konsep Ilmu-ilmu Sosial)". Proccedings Pertemuan Ilmiah Arkeologi III (pp. 35-36). Jakrta: Puslit Arkenas.

18. Valetijn, F. (1862). Oud en Niew Oost Indie, Derde Deel, Tweede Uitgave. Amsterdam: Wed. J.C. Van Kesteren \& Zoon. 